\title{
SOLITARY FIBROUS TUMOR OF THE PANCREAS: A CASE REPORT AND REVIEW OF THE LITERATURE
}

\section{Liljana Spasevska1, Vesna Janevska', Vlado Janevski², Biljana Noveska ${ }^{3}$, Julija Zhivadinovik ${ }^{4}$}

${ }^{1}$ Institute of Pathology, Faculty of Medicine, Skopje, R. Macedonia

${ }^{2}$ University Clinic of Abdominal Surgery, Skopje, R. Macedonia

${ }^{3}$ General Hospital, 8-mi Septemvri, Skopje, R. Macedonia

${ }^{4}$ Institute of Anatomy, Faculty of Medicine, Skopje, R.Macedonia

Corresponding Author: Liljana Spasevska, Institute of Pathology, Faculty of Medicine, Skopje, R. Macedonia; e-mail: lspasevska@yahoo.com

\begin{abstract}
Pancreas is an extremely rare abdominal localization of the solitary fibrous tumor (SFT). It usually grows asymptomatically for a long time before a diagnosis can be made on the basis of symptoms and/or mechanical complications. Due to the rarity and nonspecific clinical presentation, this entity is diagnostically challenging.

We present a 47-year-old man with a history of progressive epigastric pain for the last two weeks, and jaundice, who was admitted to hospital for further investigation. Cystadenocarcinoma was suspected based on the radiologic findings, and a pancreatoduodenectomy was performed. The removed portion of the pancreas contained a $3.5 \times 2 \times 1.8 \mathrm{~cm}$ well-circumscribed, but not encapsulated white tumor mass with smooth cut surface, cystic component and duct dilatation within the tumor and within the adjacent pancreatic tissue. Based on the histology and immunostaining profile, a diagnosis of the solitary fibrous tumor was made. One week post-operatively, the patient died due to surgical complications.

Microscopic and immunohistochemical examinations are necessary for accurate diagnosis of cystic SFT of the pancreas. Because there is limited data regarding the biological behavior of SFT with extra-pleural localization the authors recommend clinical follow-up for SFT treatment if the criteria of malignancy are not met.
\end{abstract}

Key words: pancreas, solitary fibrous tumors

\section{Introduction}

Pancreas is an extremely rare abdominal localization of the solitary fibrous tumor (SFT) with only 16 cases reported to date [1-16]. It usually grows asymptomatically for a long time before a diagnosis can be made on the basis of symptoms and/or mechanical complications. Due to the rarity and nonspecific clinical presentation, this entity is diagnostically challenging.

We describe a 47-year-old man with a solitary fibrous tumor arising in the head of the pancreas and review of the diagnostic literature.

\section{Case report}

A 47-year-old man with a history of progressive epigastric pain for the last two weeks, and jaundice, was admitted to hospital for further investigation. His past medical history revealed a conservative cholecystectomy performed 5 years ago. The family history including malignancy or inherited disease was unremarkable. The physical examination revealed 
icteric sclera and yellowish skin. Laboratory investigations showed a normal hemogram: hemoglobin concentration $140 \mathrm{~g} / \mathrm{L}$ (reference range: $140-180 \mathrm{~g} / \mathrm{L}$ ), hematocrit $40 \%$ (reference range: $37-54 \%$ ), platelet 290 (reference range: 140-340 ), white blood cell 8000 (reference range: 4000-8000 ), glucose (ser) $6.1 \mathrm{mmol} / \mathrm{L}$ (reference range: 3.5-6.1 mmol/L) alpha amylase (ser) 119 U/L (reference range: 30-110 $\mathrm{U} / \mathrm{L})$. Abnormal laboratory findings included elevated LDH 605 U/L (reference range: 248 $\mathrm{U} / \mathrm{L}$ ), total bilirubin $133 \mathrm{umol} / \mathrm{L}$ (reference range: 6.8-20.5 umol/L), indir.bilirubin $14 \mathrm{umol} / \mathrm{L}$ (reference range: 5.1-13.6 uml/L), dir.bilirubin $119 \mathrm{umol} / \mathrm{L}$ (reference range: $1.5-6.8 \mathrm{umol} / \mathrm{L}$ ), and alkaline phosphatase $608 \mathrm{U} / \mathrm{L}$ (reference range: 38-126 U/L). The serum tumor markers were within the normal limits for carcinoembryonic antigen $2.4 \mathrm{ng} / \mathrm{mL}$ (reference range: 1-3.4 ng/mL) and increased for carbohydrate antigen 19-9, 198.0 U/ml (reference range: 1$37 \mathrm{U} / \mathrm{ml}$ ). The abdominal ultrasonography showed a hypoechoic mass, $3.5 \mathrm{~cm}$ in cross diameter, located in the pancreatic head, without stones. The computed tomography (CT) imaging of the abdomen confirmed a $3.5 \mathrm{~cm}$ mass with enhanced contrast uptake in both arterial and venous phases on the pancreatic head. The tumor mass was well-delimited but not encapsulated, mainly solid but with a cystic component. The surrounding bile duct of the pancreaticoduodenal arcade was dilated. There was no sign of loco-regional invasion or metastasis. The diagnosis of cystadenocarcinoma was suspected and a pancreatoduodenectomy was performed.

The removed portion of the pancreas measured $10 \times 4.5 \times 3.5 \mathrm{~cm}$ and contained a $3.5 \times 2$ $\times 1.8 \mathrm{~cm}$ well-circumscribed, but not encapsulated white tumor mass with smooth cut surface, cystic component and duct dilatation within the tumor and within adjacent pancreatic tissue [Fig. 1]. The transection margin was tumor-free. The histological analysis showed that tumor had infiltrated the surrounding pancreatic parenchyma and consisted of spindle cells with eosinophilic cytoplasm and hyperchromatic nucleus with minimal cytological atypia, arranged in a fascicular pattern and with branched hemangiopericytoma-like vessels [Fig. 2, 3]. No necrosis was found and mitotic figures were very rare, 1-2 mitosis per 10 high-powered fields. Hyalinization and myxoid degeneration areas were seen in parts, which were hypocellular. The cystic component was related to retention cysts and duct dilatation. The tumor invaded the muscularis propria of the duodenum. The complete pathological examination revealed no vascular or nervous invasion. All seventeen lymph nodes were tumor-free.

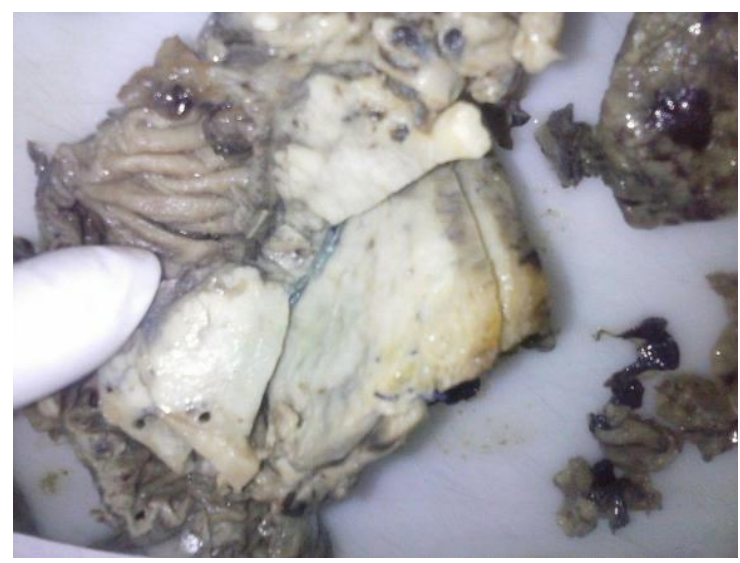

Figure 1 - Solitary, circumscribed, neoplasm with white cut surfaces, in the head of the pancreas

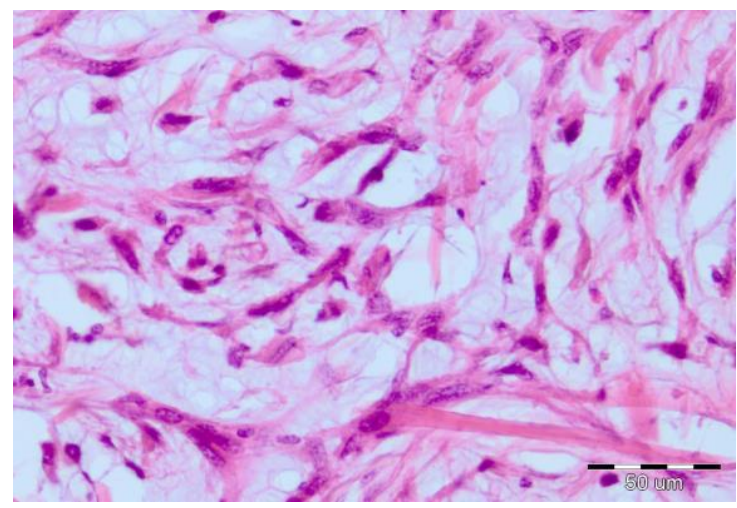

Figure 2 - Spindle cell with minimal nuclear pleomorphism $(H E \times 200)$

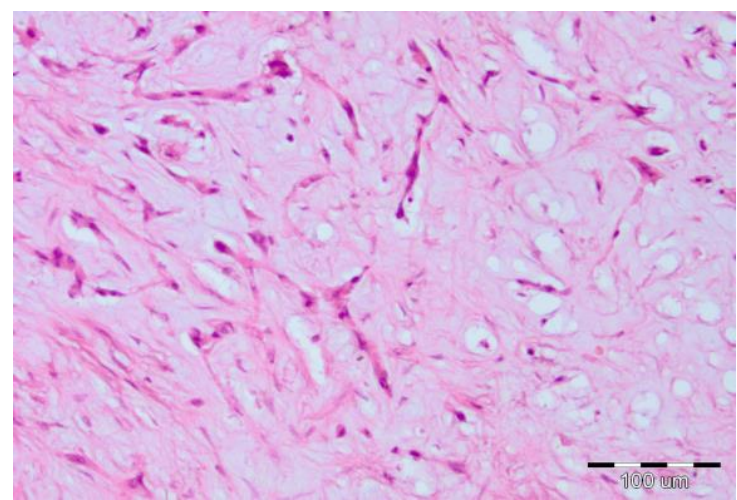

Figure 3 - Mixoid background and haemangiopericytoma-like vascular pattern $(H E \times 100)$ 
Immunohistochemical analysis on the resected tumor revealed that the tumor cells express diffusely positive for CD34, vimentin and CD99, focally positive for bcl-2, nuclear beta-catenin and actin and were negative for CD117, EMA, Caldesmon, Desmin, S100 and Cytokeratins [Fig. 4-6]. Ki-67 proliferation index was observed below $1 \%$.

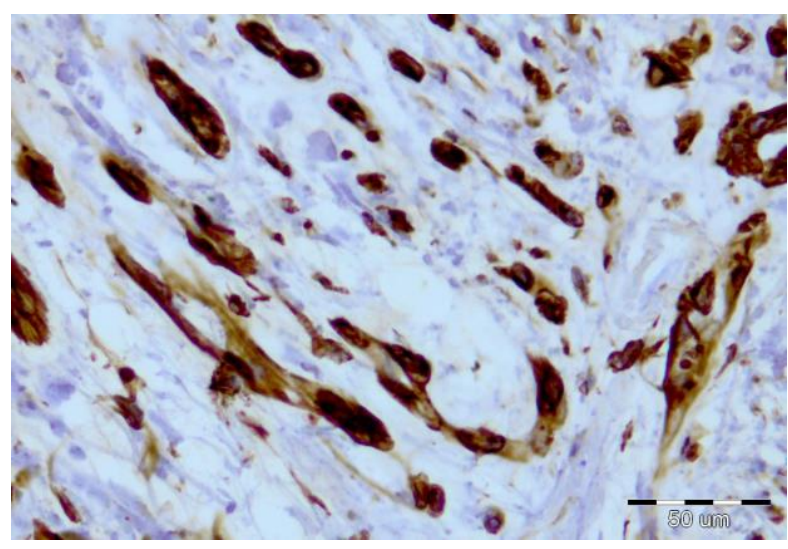

Figure 4 - Immunostaining for vimentin (× 200)

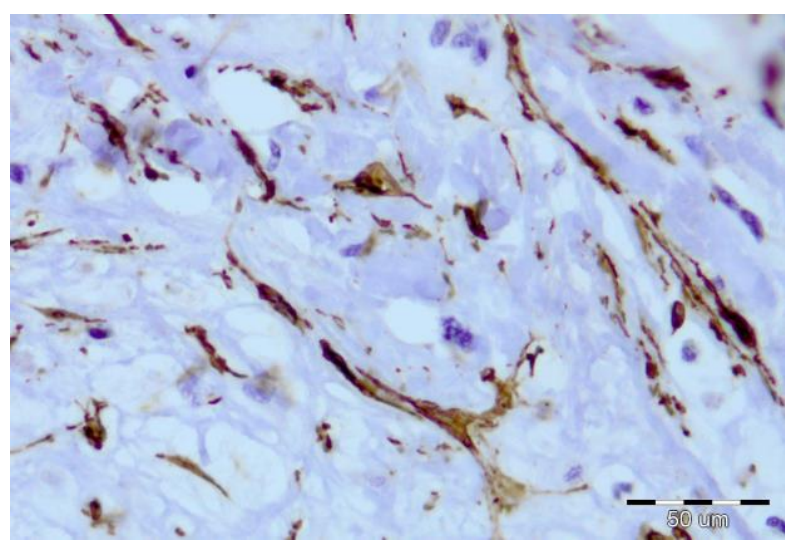

Figure 5 - Immunostaining for actin

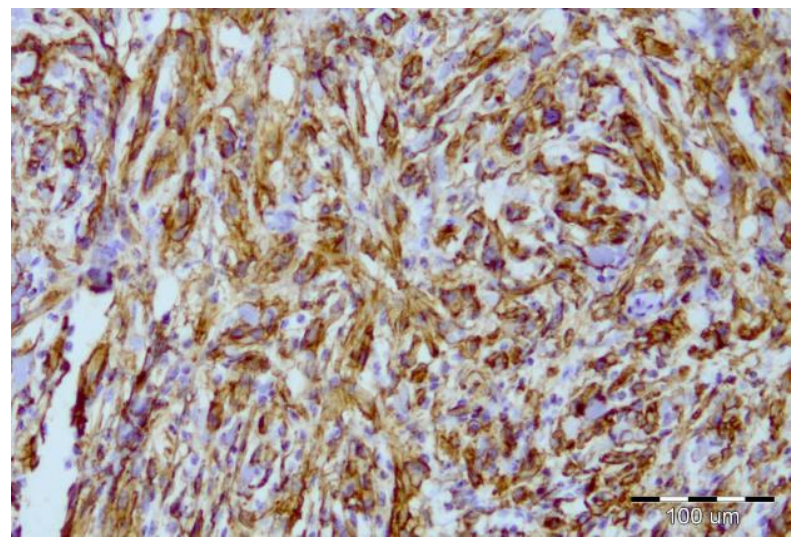

Figure 6 - Immunostaining for CD $34(\times 100)$

Based on the histology and immunostaining profile, a diagnosis of solitary fibrous tu- mor was made. One week post-operatively, the patient died due to surgical complications.

\section{Discussion}

The 2010 World Health Organization classification defines SFT as a ubiquitous mesenchymal tumor of probable fibroblastic type with a prominent haemangiopericytoma-like branching vascular pattern [15]. SFT was first described as a distinct entity among primary neoplasm in the pleura by Klemperer and Rabin in 1931 [14]. SFT is quite a rare tumor; it accounts for $0.03 \%$ of all neoplasms and $3 \%$ of soft tissue tumors, and its incidence has been estimated to be $2-4$ cases per million per year in the general population. SFT is typically found in the pleura (65\%), fascial and musculo-aponeurotic tissues, but can occur in intra-abdominal localization. Intra-abdominal SFTs are most often associated with familial adenomatous polyposis or Gardner syndrome (familial adenomatous polyposis with multiple osteomas and mesenchymal tumors of the skin and soft tissues) in up to $70 \%$ of the cases while sporadic cases are uncommon. In contrast to the intra-abdominal forms, sporadic pancreatic fibrous tumors are more frequent than those associated with familial adenomatous polyposis. SFTs in extra-pleural localizations generally exhibit benign behavior [14]. However, it has been reported that several clinical and pathological features can predict more aggressive behavior and metastasis can be seen approximately in 10-15\% of tumors [14].

In $65 \%$ of SFT cases, the tumor arises from the pleura, but they can also be found in other sites such as lung parenchyma, thyroid gland, liver, kidney, adrenal gland, salivary gland, soft tissue, head and neck. Pancreas is an extremely rare extrapleural location. Including our patient, only 16 cases of pancreatic SFTs have been reported with the clinical findings summarized in Table 1. Other mesenchymal tumors located in the pancreas include GIST, leiomyosarcoma, schwannoma, fibromyxoid sarcoma, perivascular epithelioid cell tumor (PECOoma), and vascular tumors. Pancreatic SFT is often asymptomatic because it is generally a benign and slow-growing tumor. Symptoms differ according to the location and size of the mass and include abdominal pain, constipation, jaundice, and weight loss. In our case, the patient presented with abdominal pain 
and jaundice. The patients' age ranges from 24-78 years at diagnosis [1-15]. Although extrapleural SFT has no gender bias reported, the current pancreatic cases have female to male ratio of $12: 3$. Our patient was a 47 -yearold man. In 10 cases, the radiologic impression favored an endocrine tumor, as these tumors can appear similarly well-circumscribed and hypervascular. In our case, the initial diagnosis was a cystadenocarcinoma. This was suggested because of the cystic component and female gender. In fact, the cystic component corresponded to retention cysts above the tumor. Only 4 published pancreatic SFT presented as cystic tumors. These cases confirm the difficulties of the radiologic diagnosis of the cystic pancreatic tumors. The size of the tumors ranged from 1.5 to $18.5 \mathrm{~cm}$ in diameter. SFTs were mostly localized in the head of pancreas $(9 / 13)$ as in our case. Pancreatic SFT may show a wide range of histological patterns including palisading, diffuse sclerosing areas and storiform or hemangiopericytic patterns and can thus mimic other mesenchymal neoplastic and non-neoplastic proliferations [1, 4, 7, 8]. Mixed fibrotic, hyalinized and myxoid changes might be found in stroma. The diagnosis of SFT has been refined by the availability and the immunohistochemical markers such as CD34, vimentin, bcl-2, and CD99. Nuclear beta-catenin may occur in approximately one third of SFT.

The differential diagnosis of pancreatic SFTs includes several spindle cell neoplasms such as GIST, leiomyosarcoma, schwannoma, and fibromyxoid sarcoma [10, 11, 14]. Immunohistochemically SFT expresses CD34 and vimentin in $80-90 \%$ of cases and CD99 and bcl-2 in $70 \%$ of cases. They are usually negative for c-kit (CD117), smooth muscle actin, desmin, S-100 protein and cytokeratins which are markers of GIST, leiomyosarcoma, schwannoma, and fibromyxoid sarcoma, respectively [4, 9]. Diffusely positive staining for CD34, vimentin and CD99, focally positive for bcl-2, nuclear beta-catenin and actin and negative for CD117, EMA, Caldesmon, Desmin, S100 and Cytokeratins has been obtained in our case.

There is limited data regarding the biological behavior of SFTs with extra-pleural localization, because they are rare tumors. Approximately $10-15 \%$ of the extra-pleural SFTs are malignant. A study in literature showed local recurrence after 168 months; however, most of the metastasis or a local recurrence was seen within 2 years after treatment. Lung, liver, bone, mesentery, omentum, mediastinum and retroperitoneum were distant metastasis areas in this study [14]. The criteria for malignancy include large tumor size ( $>50 \mathrm{~mm})$, disseminated disease at presentation, infiltrative margins, and histologic features consistent with high cellularity, nuclear pleomorphism, areas of tumor necrosis, and an increased mitotic index ( $>4$ mitoses/10 high powered fields) [15]. Malignant SFTs have reduced CD34 immunoreactivity. Relapse was seen in $80 \%$ of these cases. However, in our case no pleomorphism and necrosis was found and mitotic figures were very rare, less than 1-2 mitosis per 10 per highpowered fields. Ki-67 proliferation index has been observed below $1 \%$ and tumor was diagnosed as a benign.

In the cases of intra-abdominal SFTs, complete tumor resection is the treatment of choice [1, 3, 4, 6, and 7].

In conclusion, we report a rare case of pancreatic SFT. Cystic SFT of the pancreas is difficult to radiologically distinguish from other cystic pancreatic tumors. Microscopic and immunohistochemical studies are necessary for accurate diagnosis. Because there is limited data regarding biological behavior of SFT with extra-pleural localization the authors recommend clinical follow-up for SFT treatment if the criteria of malignancy are not met. 
Table 1

Comparative data of patients with solitary fibrous tumors of the pancreas

\begin{tabular}{|c|c|c|c|c|c|c|c|}
\hline Case & Author & Age & Gender & Clinical presentation & \begin{tabular}{|l|} 
Tumor \\
size $(\mathrm{cm})$ \\
\end{tabular} & $\begin{array}{l}\text { Location in } \\
\text { the pancreas }\end{array}$ & Immunostaining (+) \\
\hline 1 & $\begin{array}{l}\text { Lüttges } \\
1999\end{array}$ & 50 & Female & $\begin{array}{l}\text { Absent/incidental } \\
\text { finding }\end{array}$ & 5.5 & Body & $\begin{array}{l}\text { CD34, CD99, bcl-2, } \\
\text { vimentin }\end{array}$ \\
\hline 2 & $\begin{array}{l}\text { Chatti } \\
2006\end{array}$ & 41 & Male & Abdominal pain & 13 & Body & $\begin{array}{l}\text { CD34, CD99, bcl-2, } \\
\text { vim }\end{array}$ \\
\hline 3 & \begin{tabular}{|l} 
Gardini \\
2007 \\
\end{tabular} & 62 & Female & Abdominal pain & 3 & Head & $\begin{array}{l}\text { CD34, CD99, bcl-2, } \\
\text { vim }\end{array}$ \\
\hline 4 & \begin{tabular}{|l|} 
Miyamoto \\
2007
\end{tabular} & 41 & Female & $\begin{array}{l}\text { Right upper quadrant } \\
\text { abdominal pain }\end{array}$ & 2 & $\begin{array}{l}\text { Head/body } \\
\text { junction }\end{array}$ & CD34, bcl-2 \\
\hline 5 & $\begin{array}{l}\text { Kwon } \\
2008 \\
\end{array}$ & 54 & Male & $\begin{array}{l}\text { Absent/incidental } \\
\text { finding }\end{array}$ & 4.56 & Body & CD34, CD99, vim \\
\hline 6 & $\begin{array}{l}\text { Srinivasan } \\
2008\end{array}$ & 78 & Female & $\begin{array}{l}\text { Back pain, weight } \\
\text { loss }\end{array}$ & 5 & Body & $\begin{array}{l}\text { CD34, CD99, bcl-2, } \\
\text { vim }\end{array}$ \\
\hline 7 & $\begin{array}{l}\text { Amiot } \\
2008\end{array}$ & 51 & Female & Epigastric pain & 6 & Tail & Anti-beta-catenin \\
\hline 8 & \begin{tabular}{|l|} 
Chetty \\
2009 \\
\end{tabular} & 67 & Female & $\begin{array}{l}\text { Absent/incidental } \\
\text { finding }\end{array}$ & 2.6 & Head & CD34, CD99, bcl-2 \\
\hline 9 & \begin{tabular}{|l} 
Ishiwatarii \\
2009 \\
\end{tabular} & 58 & Female & $\begin{array}{l}\text { Absent/incidental } \\
\text { finding }\end{array}$ & 3 & Head & CD34, bcl-2 \\
\hline 10 & \begin{tabular}{|l} 
Sugawara \\
2010
\end{tabular} & 55 & Female & $\begin{array}{l}\text { Absent/incidental } \\
\text { finding }\end{array}$ & 7 & Body & CD34 \\
\hline 11 & \begin{tabular}{|l|} 
Santos \\
2012 \\
\end{tabular} & 40 & Female & $\begin{array}{l}\text { Absent/incidental } \\
\text { finding }\end{array}$ & 3 & Body & CD34, $\beta$-catenin \\
\hline 12 & $\begin{array}{l}\text { Tasdemir } \\
2012\end{array}$ & 24 & Female & Abdominal pain & 18.5 & Body & CD34, vim \\
\hline 13 & $\begin{array}{l}\text { Chen } \\
2013\end{array}$ & 49 & Female & $\begin{array}{l}\text { Mild pain in the } \\
\text { upper abdomen }\end{array}$ & 13 & Head & $\begin{array}{l}\text { CD34, bcl-2, vim, } \\
\text { muscle-specific actin } \\
\text { (MSA), CD68, Ki67 }\end{array}$ \\
\hline 14 & $\begin{array}{l}\text { Hwang } \\
2014\end{array}$ & 53 & Female & $\begin{array}{l}\text { Absent/incidental } \\
\text { finding }\end{array}$ & $\begin{array}{l}5.2 \text { and } \\
1.8\end{array}$ & Head & $\begin{array}{l}\text { CD34, bcl-2, muscle- } \\
\text { specific actin } \\
\text { MSA),CD10, ER, PR }\end{array}$ \\
\hline 15 & \begin{tabular}{|l|} 
Hee Han \\
2015
\end{tabular} & 77 & Female & $\begin{array}{l}\text { Jaundice without } \\
\text { other symptoms }\end{array}$ & 1.5 & Head & CD34, CD99 \\
\hline 16 & $\begin{array}{l}\text { Baxter } \\
2015\end{array}$ & 58 & Female & $\begin{array}{l}\text { Left lower quadrant } \\
\text { abdominal pain }\end{array}$ & 3.5 & Head & CD34, bcl-2, \\
\hline 17 & Current case & 47 & Male & $\begin{array}{l}\text { Jaundice, abdominal } \\
\text { pain }\end{array}$ & 3.5 & Head & $\begin{array}{l}\text { CD34, CD99, bcl-2, } \\
\text { vim, } \beta \text {-catenin, actin }\end{array}$ \\
\hline
\end{tabular}

\section{REFERENCES}

1. Miyamoto H, Molena DA, Schoeniger LO, Haodong $\mathrm{Xu}$. Solitary fibrous tumor of the pancreas: a case report. Int J Surg Pathol. 2007; 15(3): 311-4.

2. Gardini A, Dubini A, Saragoni L, Padovani F, Garcea D. Benign solitary fibrous tumor of the pancreas: a rare location of extra-pleural fibrous tumor. Single case report and review of the literature. Pathologica. 2007; 99: 15-8.

3. Kwon HJ, Byun JH, Kang J, Park SH, Lee MG. Solitary fibrous tumor of the pancreas: imaging findings.Korean J Radiol. 2008; 9(Suppl.): S48-51.

4. Srinivasan VD, Wayne JD, Rao MS, Zynger DL Solitary fibrous tumor of the pancreas: case report with cytological and surgical pathology correlation and review of the literature. JOP 2008; 9: 526-30.

5. Chetty R, Jain R, Serra S Solitary fibrous tumor of the pancreas. Ann Diagn Pathol. 2009; 13: 339-43.
6. Sugawara Y, Sakai S, Aono S, Takahashi T, Inoue T, Ohta K et al. Solitary fibrous tumor of the pancreas. Jpn J Radiol. 2010; 28: 479-82.

7. Luttges J, Mentzel T, Hubner G, Kloppel G. Solitary fibrous tumour of the pancreas: a new member of the small group of mesenchymal pancreatic tumors. Virchows Archiv. 1999; 435: 37-42.

8. Chatti K, Nouira K, Ben Reguigua M, Bedioui $H$, Oueslati S, Laabidi B, et al. Solitary fibrous tumor of the pancreas. A case report. Gastroenterol Clin Biol. 2006; 30: 317-9.

9. Baxter AR, Newman E, Hajd CH. Solitary fibrous tumor of the pancreas. J Surg Case Rep. 2015; 2015(12): rjv144.

10. Santos LAM, Santos VM, Oliveira OCG, De Marco M. Solitary fibrous tumors of the pancreas: a case report. An. Sist. Sanit. Navar. 2012; 35(1): 133-36.

11. Hwang JD, Kim JW, Chang JC. Imaging findings of a solitary fibrous tumor in pancreas: a case report. J Korean Soc Radiol. 2014; 70(1): 53-7. 
12. Chen JW, Lu T, Liu HB, Tong SX, Al ZL, Suo T, Ji Y. A solitary fibrous tumor in the pancreas. Chin Med J. 2013; 126(7): 1388-9.

13. Ishiwatarii H, Hayashi T, Yoshida M, Kuroiwa G. A case of solitary fibrous tumor of the pancreas. Nippon Shokakibyo Gakkai Zasshi. 2009; 106: 1078-85.

14. Tasdemir A, Soyuer I, Yurci A, Karahanli I, Akyildiz H. A huge solitary fibrous tumor localized in the pancreas: a young women. JOP. J Pancreas (Online). 2012; 13(3): 304-7.

15. Han HS, Baek HY, Han SY, Lee SW, Jeong JS, Cho JH, Kwon HJ. Solitary fibrous tumor of the pancreas: a case report and review of the literature. Korean $\mathrm{J}$ Med. 2015; 88(3): 293-8.

16. Amiot A, Dokmak S, Sauvanet A, Vilgrain V, Bringuier PP, Scoazec JY, et al. Sporadic desmoid tumor. An exceptional cause of cystic pancreatic lesion. JOP. 2008 ; 9(3): 339-45.

Резиме

\section{СОЛИТАРЕН ФИБРОЗЕН ТУМОР НА ПАНКРЕАС: ПРИКАЗ НА СЛУЧАЈ И ПРЕГЛЕД НА ЛИТЕРАТУРА}

\section{Лилјана Спасевска ${ }^{1}$, Весна Јаневска ${ }^{1}$, Владо Јаневски ${ }^{2}$, Билјана Новеска ${ }^{3}$, Јулија Живадиновиќ ${ }^{4}$}

${ }^{1}$ Институт за патологија, Медицински факултет, Скопје, Р. Македонија

${ }^{2}$ Универзитетска клиника за абдоминална

хирургија, Скопје, Р. Македонија

${ }^{3}$ Општа болница, 8 Септември,

Скопје, Р. Македонија

${ }^{4}$ Институт за анатомија, Медицински факултет, Скопје, Р. Македонија

Солитарните фиброзни тумори (СФТ) исклучително ретко се јавуваат во панкреасот. Тие обично се развиваат асимптоматски и тоа подолг временски период пред да може да се постави дијагноза врз основа на симптомите и/или механички предизвиканите компликации. Поради реткоста и неспецифичната клиничка слика, овој ентитет претставува вистински дијагностички предизвик.

Прикажуваме случај на 47-годишен маж со историја на прогресивна епигастрична болка во тек на две недели и појава на жолтица, кој беше хоспитализиран за понатамошно испитување. Врз основа на радиолошките наоди, поставена е дијагноза на цистаденокарцином, по што е направена панкреатодуоденектомија. Отстранетиот дел од панкреасот содржеше добро ограничена, неинкапсулирана, бела туморска маса со димензии $3.5 \times 2 \times 1.8 \mathrm{~cm}$. На пресек творбата беше мазна. Видливи беа цистични компоненти и дилатација на каналите во туморското ткиво и во ткиво на панкреасот во непосредната близина. Врз основа на хистолошката и имунохистохемиската анализа беше поставена дијагноза на солитарен фиброзен тумор. Една недела по операцијата, пациентот почина поради хируршки компликации.

За поставување точна дијагноза на цистичен СФТ на панкреас, неопходни се микроскопски и имунохистохемиски испитувања. Податоците за биолошкото однесување на СФТ со екстраплеврална локализација се ограничени, па затоа, и кога не се исполнети критериумите за малигнитет, авторите препорачуваат клиничко следење при третманот на СФТ.

Клучни зборови: панкреас, солитарен фиброзен тумор 